\title{
Avrupa Ülkelerinden Türkiye'ye Yönelik Turizm Talebini Etkileyen Faktörler: Panel Veri Analizi
}

\section{Dr. Ümit Şengel ${ }^{1 *}$}

Prof. Dr. Burhanettin Zengin ${ }^{2}$

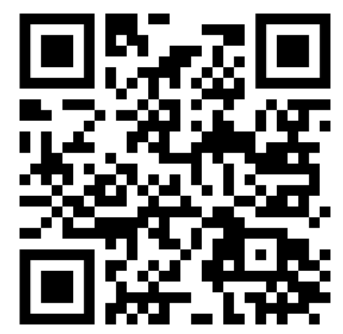

Geliş tarihi: 19.09.2020

Kabul tarihi: 10.11 .2020

\section{Atıf bilgisi:}

IBAD Sosyal Bilimler Dergisi

Sayı: Özel Sayı Sayfa: 304-316

Yıl: 2020

This article was checked by intihal.net. Similarity Index 06\%

Bu makalede araştırma ve yayın etiğine uyulmuştur.

${ }^{1}$ Sakarya Uygulamalı Bilimler Üniversitesi, Türkive, umitsengel@gmail.com ORCID ID 0000-0003-1284-836X

${ }^{2}$ Sakarya Uygulamalı Bilimler Üniversitesi, Türkiye, bzengin@gmail.com ORCID ID 0000-0002-6368-0969

\footnotetext{
* Sorumlu yazar
}

öz

Rekabetin giderek yoğunlaștığı turizm pazarında arz ve talep önemli kavramlar olarak öne çıkmaktadır. Destinasyonlar bu yoğun rekabet ortamında tercih edilebilmenin yollarını aramaktadır. Dolayısıyla her bir destinasyon için talebi etkileyen faktörlerin bilinmesi önem taşımaktadır. $\mathrm{Bu}$ araştırmada, Avrupalı turistlerin Türkiye'ye olan taleplerini etkileyen faktörlerin tespit edilmesi amaçlanmaktadır. Bu kapsamda, Batı Avrupa ve Avrupa Birliği ülkelerinin ekonomik, sosyo-demografik, turizm-seyahat ve teknoloji ile ilgili değişkenlerinden hangilerinin belirleyici olabildiği test edilmektedir. Araştırmada nicel araştırma yöntemleri kullanılmıştır. Analize edilen veriler ülkelere ait resmi verilerdir. Veri analizinde Panel veri ekonometrisi kullanılmıştır. Araştırmanın sonuçlarına göre teknoloji değişkenleri dışındaki diğer değişkenlerin çoğunun Avrupa ülkelerinden Türkiye'ye yönelik talebi etkilediği görülmektedir. Bununla beraber, Avrupa ülkelerinin ekonomik, sosyo-demografik ve turizm-seyahat yapılarıyla ilgili değişkenlerin bölgeden Türkiye'ye yönelik turizm talebini etkilediği de tespit edilmiştir.

Anahtar Kelimeler: Avrupa Ülkeleri, Turizm Talebi, Türkiye, Panel Veri Analizi 
Factors Affecting Tourism Demand for Turkey from the European Countries: Panel Data Analysis

\section{Dr. Ümit Şengel ${ }^{1 *}$ \\ Prof. Dr. Burhanettin Zengin ${ }^{2}$}

First received: 19.09 .2020

Accepted: 10.11 .2020

\section{Citation:}

IBAD Journal of Social Sciences

Issue: Special Issue Pages: $304-316$

Year: 2020

This article was checked by intihal.net. Similarity Index 06\%

\footnotetext{
${ }^{1}$ Sakarya University of Applied Sciences, Turkey, umitsengel@gmail.com ORCID ID 0000-0003-1284-836X
}

2 Sakarya University of Applied Sciences, Turkey, bzengin@gmail.com ORCID ID 0000-0002-6368-0969

\footnotetext{
* Corresponding Author
}

\begin{abstract}
In the tourism market, where competition is increasingly intensified, supply and demand stand out as important concepts. Destinations are looking for ways to be preferred in this intense competitive environment. Therefore, it is important to know the factors affecting demand for each destination. In this study, the factors influencing the demands of European tourists to Turkey, which are intended to be identified. In this context, which of the economic, socio-demographic, tourismtravel and technology variables of Western European and European Union countries can be determined. Quantitative research methods were used in the research. The data subject to analysis are official data of the countries. Panel data econometrics are used in data analysis. Many of the other variables outside variables technology based on the results of the research shows that affect the demand for Turkey from the European countries. At the same time, economic, socio-demographic and tourism-travel structure variables of European countries have been detected that affect the demand for tourism to Turkey from the region.
\end{abstract}

Keywords: European Countries, Tourism Demand, Turkey, Panel Data Analysis 


\section{GİRIŞ}

Dünyaya etkileri büyük boyutlara ulaşan küreselleşme bilimsel değerlendirmelerde kabul gören ve birçok alanda ağırlığını hissettiren modern terimlerden biridir. Kavram, iletişimi çok boyutlu ve hızlı seviyeye getirmektedir. Ayrıca ulusal pazarların dış ticaret ve sermaye dolaşımında serbest hareket etmeyi sağlayan bu süreç sayesinde ulusal firmalar ve pazarlar uluslararası bir kimliğe kavuşmaktadır. $\mathrm{Bu}$ durum rekabet şartları ağır bir uluslararasılaşma sürecini meydana getirmektedir (Taptık ve Keleş, 1998).

Bilgi ve iletişim teknolojilerinde (BIT) meydana gelen hızlı artış dünyayı küresel bir köy haline getirmektedir. BIT'lerdeki artış dünyayı küçük bir yer haline getiren yapısıyla birçok alanda kendini hissettirmektedir. Başta ekonomi olmak üzere politika, insan hakları, çevre, kültür, hukuk gibi birçok alanda bu teknolojilerden istifade edilmekte ve bu alanlar bu teknolojilere göre şekillenmektedir. $\mathrm{Bu}$ alanların ortak özelliği en ufak değişimlerin bireysel veya toplumsal hayatı etkilemesidir. Dolayısıyla BİT'lerdeki gelişmeler küreselleşmeyi, küreselleşmedeki gelişmeler ise birey ve toplum yaşamını etkilemektedir (Çeken ve diğerleri, 2008).

Dünyada yaşanan bu gelişmelerin etkilediği spesifik ve en kedine has özellikleri bulunan alanların başında turizm gelmektedir. Turizm'de küreselleşme süreciyle paralel olacak şekilde 20. yüzyılın ikinci yarısından başlayarak çok önemli bir ilerleme kaydetmiştir. Bu süreçte turizm talebi hızlı bir artış gösterirken, ülkelerde bu talebe cevap verecek şekilde turistik yatırımlar yapmaya başlamıştır. Turizmde yaşanan bütün gelişmeler turizmi ekonomik güçleri olan büyük bir endüstri haline getirmiştir. $\mathrm{Bu}$ ekonomik güçler firma ve hane halkı düzeyinde mikro ekonomik etkiler anlamında kendini göstermekte ve ülkelere katkı sağlamaktadır. Ancak ülkelerin esas üzerinde durdukları turizmin makroekonomik etkileridir. GSMH, gelir, dış ödemeler dengesi, ekonomik büyüme, istihdam ve toplumsal kalkınma gibi birçok makroekonomik parametrede turizmin etkilerini görmek mümkündür (Çımat ve Bahar, 2003; Kar ve diğerleri, 2004).

Dış ticaretleri açık veren ülkeler döviz problemlerini çözmek için turizme ciddi şekilde önem vermektedir. Özellikle gelişmekte olan ülkelerin yaşadığı döviz problemlerinin giderilmesi için üzerinde durulan bir alternatif kaynaktır (Topallı, 2015). Turizm bölgeler arasında yer alan kalkınma ve gelişmişlik farklılıklarını ortadan kaldırması bakımdan da önemlidir. (Avcıkurt, 2003; Alaeddinoğlu, 2006; Selçuk ve Çatal, 2007; Yeşiltaş ve Öztürk, 2008; Şengel, 2015; İbiş ve Batman, 2015). Ülkeler tüm ekonomik göstergeler başta olmak üzere turizmin sosyal, kültürel ve çevresel etkileri nedeniyle turizm faaliyetlerini geliştirmek için güçlü bir çaba harcamaktadır. Bu nedenle kendilerine yönelik olan turizm talebini etkileyen faktörleri tespit etmek ve buna göre hareket etmektedirler.

Bu araştırmada Türkiye'ye yönelik turizm talebini etkileyen faktörlerin ekonomik, sosyo-demografik, turizm-seyahat ve teknolojik değişkenler bağlamında tespit edilmesi amaçlanmaktadır. Özellikle değişkenlerin turist gönderen ülkelerle ilgili olması çalışmayı farklı ve önemli kılmaktadır. Ayrıca teknoloji ve seyahatle ilgili değişkenlerin olması çalışmayı daha da önemli hale getirmektedir. Bundan hareketle 1992 yılından itibaren Türkiye'ye en çok turist gönderen Avrupa ülkeleriyle ilgili verilerin elde edilip analiz edilmesi hedeflenmektedir. Bu araştırmanın sonuçlarının, Türkiye'nin turizm politikalarına uygun olacak şekilde yapılan tanıtım faaliyetlerine katkı sağlayacağı düşünülmektedir. Türkiye'ye olan turizm talebinde etkili olan faktörlerin turistlerin geldikleri ülkelere göre belirlenmesi, bu faktörlerin ön planda tutulduğu bir pazarlama sürecinin başarısını da beraberinde getirebilir.

\section{LITERATÜR TARAMASI}

Turizm talebi ile ilgili çok sayıda çalışmanın literatürde yer aldığı bilinmektedir. Herhangi bir destinasyona yönelik talep tahminlerinin yapılması veya bu talebi etkileyen faktörlerin tespit edilmesi oldukça önemlidir. Çünkü destinasyonlar bu araştırmalarda ortaya çıkan sonuçlara göre hareket ederek turizm pazarında pay alabilmek için birtakım uygulamalara başvurmakta, turizm plan ve politikalarını buna göre belirleyen stratejiler izlemektedir.

Turizm talebini etkileyen faktörlerin ölçüldüğü çalışmalarda bağımlı değişken genellikle turist sayısı veya turizm geliridir (Dritsakis, 2004; Ouerfelli, 2008). Bağımsız değişkenler ise çalışmanın tasarımına bağlı olarak değişebilmektedir. Bu değişkenlerin en fazla yoğunlaştıkları konu ekonomidir. Bu nedenle, 
gelir, hizmet fiyatları, seyahat maliyeti veya döviz kurları gibi değişkenlerin test edildiği çalışmalara sıklıkla rastlanılmaktadır (Lim, 1997). Bununla birlikte büyük spor organizasyonları, fuar veya sergiler, savaş veya diğer beklenmedik olayların da bağımsız değişken olarak kullanıldığı görülmektedir (Aydın ve diğerleri, 2015). Ayrıca büyük ekonomik krizler, saygın hastalıklar ve terör eylemleri gibi değişkenlerde kullanılmaktadır (Wang, 2009)

Uluslararası literatürde dış turizm talebinin belirleyici faktörlerinin tespit edilmesiyle ilgili çok sayıda çalışma yürütülmüştür. Bu çalışmalardan en önemlilerinden biri de Gholipour ve arkadaşları (2014) tarafindan gerçekleştirilmiştir. 80 ülke için 1999-2011 dönemindeki verilerle yapılan araştırmada bir ülkedeki özgürlük seviyesi ile dış pasif turizm talebi arasında ilişki tespit edilmiştir. Ülkelerin özgürlükleri kısıldıkça ülke insanları daha fazla seyahat eğilimi taşımakta ve dış turizme katılmak istemektedir. Bu bulgular için ülkelerin gelişmişlik kriteri önemli bir bulgu olarak karşımıza çıkmaktadır. Yani ülkelerin gelişmişliği düştükçe bu tespit anlam kazanmaya başlıyor.

Lim ve McAleer (2002) yıllık verilerle yapıkları araştırmada Malezya'nın turizm talebini etkileyen faktörleri tespit etmeye çalışmıştır. Araştırmada uluslararası turizm talebi, ulaşım maliyetleri ve döviz kurları ile turizm arasında uzun dönemli bir denge ilişkisi ortaya konmaktadır. İlgili çalışmada, reel gelirin bu değişkenlerle ortak bir ilişkisi tespit edilmemektedir. Bu açıklanabilir bir durumdur. Bazen veri alınan zaman periyodu, verisi alınan ülke grubu veya talebin olacağı ülkedeki modele dahil edilmeyen diğer değişkenler nedeniyle beklenmeyen sonuçlar ortaya çıabilmektedir.

Dritsakis ve Athanasiadis (2000) Yunanistan'a yönelik turizm talebini etkileyen faktörleri araştırmışlardır. İsveç Finlandiya, ABD, Japonya, İsviçre ve Norveç gibi ülkelerden Yunanistan'a yönelik turizm talebi için hangi faktörlerin belirleyici olduğu tespit edilmiştir. Yapılan çalışmaya göre ilgili ülkelerin kişi başına harcanabilir gelirleri Yunanistan'a yönelik talebi etkilememektedir. Ancak, ortalama toplam maliyetin ve seyahat maliyeti, yatırım, döviz kuru ve turist gönderen ülkelerin politik istikrarları bu talebi etkilemektedir. Yunanistan'daki terör ve şiddet eylemleri de etkisi diğerlerine oranla az olmakla birlikte turizm talebini etkilemektedir.

Dünya genelinde farklı ülkeler arası dış turizm talebi belirleyici unsurlarının araştırıldığı başka çalışmalarda söz konusudur. Crouch (1995), uluslararası turizm talebini etkileyen, gelir seviyesi, ulusal fiyat düzeyleri, döviz kurları, seyahat maliyetleri ve turizm pazarlama giderleri gibi faktörleri ortaya koymuştur. Turizm bölgesi tercihlerini etkileyen faktörleri ele alan Ouerfelli (2008), fiyat ve gelir gibi değişkenler yanında, rakip ülkelerin fiyatları ve arz faktörlerini ekonomik modeline ekleyerek bunların talepte belirleyici unsurlar olduğunu ortaya koymuştur. Habibi ve arkadaşları (2008) çalışmalarında Turizm talebini etkileyen kaynak ülkenin geliri, turizm fiyatları ve taşıma maliyetleri gibi değişkenleri tespit etmişlerdir. Wang (2009), döviz kurları, gelir, turizm fiyatları, seyahat maliyetleri gibi ekonomik faktörlerin, Schiff ve Becken (2011), turistlerin harcamaları ve ekonomik krizlerin, Jintranun ve arkadaşları (2011) politik istikrasızlık, SARS salgını, tsunami, tüketici fiyat endeksi, kaynak ülkenin geliri, ulaşım maliyetleri ve döviz kurunun turizm talebini etkilediğini tespit etmiştir.

Türkiye'ye yönelik turizm talebini etkileyen faktörlerin incelendiği araştırmalar farklı dönemlerde çalışılmıştır. İçöz ve arkadaşları (1997) İsviçre, Hollanda, Finlandiya, Almanya Avusturya, Belçika, İtalya Fransa, İngiltere ve Yunanistan'dan Türkiye yönelik turizm talebini etkileyen faktörler olarak bir dizi bağımsız değişkeni incelemiştir. Çalışmada etkilerinin şiddeti değişmekle birlikte yatak kapasitesi, Türkiye'nin döviz kuru, seyahat acentesi sayısı, tüketici fiyat endeksi gibi değişkenlerin farklı ülkelerden Türkiye'ye yönelik turizm talebinin belirleyicileri olarak ortaya çıkmıştır.

Akış (1998) Türkiye en fazla turist gönderen 18 ülkeden Türkiye'ye yönelik turizm talebini etkileyen faktörlerin belirlemek için 13 yıllık dönemin verileriyle regresyon analizi gerçekleştirmiştir. Araştırmaya göre turistlere kaynaklık eden ülkelerin gelirleri ile göreceli fiyat ve reel döviz kuru gibi değişkenlerin talebi etkilediğini tespit etmiştir.

Aktaş (2005) yaptığı çalışmada turizm talebini ölçerken bağımlı değişken olarak turizm gelirlerini kullanmıştır. Araştırmada bağımsız değişkenler arz ve talep faktörleri bağlamında oluşturulmuştur. 20 yıllık dönemi kapsayan araştırma sonuçlarına göre Türkiye'nin turizm gelirlerini yatak kapasitesi, seyahat acentası, yabancı sermaye, döviz kuru, tanıtım bütçesi gibi değişkenler etkilemektedir. 
Görmüş ve Göçer (2010) yaptıkları çalışmaya göre ülkeler arasındaki ticaret hacmi, yatak kapasitesi ve turist gönderen ülkelerin GSMH'si gibi değişkenler Türkiye yönelik turizm talebini olumlu etkilerken, ülkeler arası mesafe değişkeni bu talebi negatif olarak etkilemektedir. Kaya ve Canlı (2013) OECD ülkelerine yönelik yaptıkları çalışmada, bu ülkelerden Türkiye'ye yönelik turizm talebinin gelir, fiyat düzeyi, ve ikame destinasyonların fiyatları gibi değişkenlerce açıklandığını tespit etmiştir. Güneş ve Kabaday1 (2015) ise Türkiye'nin turizm talebini etkileyen faktörleri inceledikleri çalışmada, ziyaretçilerin kişi başı GSYIH'ları, nüfus sayıları, başkentlerinin İstanbul'a olan mesafeleri, Türkiye'ye ile olan politik ve askeri ilişleri, din ve etnik yapılar gibi değişkenlerin Türkiye'ye yönelikte turizm talebinde belirleyici faktörler olduğunu ortaya koymuştur.

\section{YÖNTEM}

Araştırmada nicel araştırma yöntemlerinden yararlanılmıştır. Veriler ülkelere ait istatistiklerden oluşan ikincil verilerdir. Araştırmanın tasarlanma aşamasında mümkün olduğu kadar geniş bir zaman aralığı ve farklı kategorideki Avrupa ülkelerinin araştırmaya dâhil edilmesi planlanmıştır. Gerek 24 Ocak liberal ekonomi kararları gerek 2634 sayılı turizm teşvik kanunu olmak üzere iki önemli gelişmenin 1980'li yılların başına denk gelmesi ve Türkiye'de turizm faaliyetlerini etkilemesi nedeniyle 1980 yıllından başlanarak verilerin toplanması hedeflenmiştir. Bu amaçla 1980 yılından itibaren "milliyetlerine göre Türkiye'ye gelen turist sayısı" ve "milliyetlerine göre turistlerin Türkiye'de yaptıkları turizm harcaması" olmak üzere iki bağımlı değişkene ilişkin veri araştırması yapılmıştır. Türkiye'de turistlerin milliyetlerine göre yaptıkları turizm harcaması ile ilgili düzenli ve sistematik bir veri bulunmadığından, tek bağımlı değişken olarak "milliyetlerine göre Türkiye'ye gelen turist sayısı”" değişkeni kullanılmıştır.

Yapılan çalışmalar ve değerlendirmeler sonucunda araştırma kapsamında kullanılan veri seti 1992-2017 yılları arasını kapsayan 26 yıllık bir dönem olarak kararlaştırılmıştır. Türkiye'ye yönelik turizm talebinin incelenmesi için veri Avrupa Birliği ve Batı Avrupa için analizler gerçekleştirilmiştir.

Bağımlı değişkene ait verilerin elde edilmesinde Kültür ve Turizm Bakanlığı Yatırım ve İşletmeler Genel Müdürlüğünün turizm istatistiklerinden yararlanılmıştır. Ayrıca bu veriler TÜİK verileri de dikkate alınarak gözden geçirilmiştir. Turist gönderen ülkelere (Avrupa Birliği ve Batı Avrupa) ait ve bağımsız değişkenleri oluşturan ekonomik, sosyo-demografik, turizm-seyahat ve teknolojik değişkenlerden sayısal verileri olanlar için Dünya Bankasının erişime açık veri tabanından yararlanılırken, kukla değişkenlere ise sahip olunan belli özellikler göz önünde bulundurularak (Heckman, 1975; Karafiath, 1988; LaVeist, 1995; Atakan, 2008; Acaravc1 ve Bostan, 2011; Gujarati ve Porter, 2014) veriler atanmıştır.

Türkiye'ye yönelik turizm talebini etkileyen faktörlerin belirlendiği ve 26 yıllık bir dönemi kapsayan bu çalışmada biri bağımlı, 41'i bağımsız olmak üzere toplam 42 değişkenle analiz sürecine başlanmıştır. Bağımsız değişkenlerden üç değişkene ait veriler program ile uyumlu olmadığı için bu değişkenler analiz yapılırken kullanılmamıştır. Akabinde çoklu doğrusal bağlantı testi Varyans Artış Faktörü (Variance Inflation Factors - VIF) yapılmıştır. VIF değeri 10 ve üzeri olan bağımsız değişkenlerin (Sevinç, 2013: 2) diğer bağımsız değişkenler tarafindan açıklandığı için 14 değişken daha devre dışı bırakılmış ve toplamda 24 değişken üzerinden analizler gerçekleştirilmiştir.

Değişkenlerin kullanım durumlarını gösteren bilgilerin anlaşılır olması için bir arada verilmeleri öngörülmüş ve değişkenlere ait kullanım durumlarını gösteren bilgiler Tablo 1'de verilmektedir. Daha önce de ifade edildiği gibi analizler 41 bağımsız değişkenin 24'ü üzerinden yapılmıştır. Analize tabi tutulan değişkenler ekonomik, Sosyo-demografik, turizm-seyahat ve teknoloji ile ilgili değişkenlerdir. Turizm talebi ile turizm talebini etkileyen faktörler arasındaki ilişki regresyon modeli yardımıyla açıklanmıştır. 
Tablo 1. Araştırmadaki Değişsenler ve Kullanım Durumları

\begin{tabular}{|c|c|c|}
\hline \multicolumn{2}{|r|}{ DEĞİŞKEN } & \multirow[t]{2}{*}{ KULLANIM DURUMU } \\
\hline $\mathbf{Y}$ & Milliyetlerine Göre Turist Sayısı (Bağımlı) & \\
\hline $\mathbf{X}_{1}$ & GSYH (Dolar) & Kullanıld 1 \\
\hline $\mathbf{X}_{2}$ & Kişi Başı Harcanabilir Gelir (Dolar) & Kullanıld1 \\
\hline $\mathbf{X}_{3}$ & Y1llık Büyüme Oranı & Kullanıldı \\
\hline $\mathbf{X}_{4}$ & Gini Katsayıs1 (\%) & Kullanıldı \\
\hline $\mathbf{X}_{5}$ & İstihdam (İşgücü) & Kullanıld1 \\
\hline $\mathbf{X}_{6}$ & İşsizlik (Yüzde) & Kullanıld 1 \\
\hline $\mathbf{X}_{7}$ & Gider (GSYH \%’si) & Kullanıldı \\
\hline $\mathbf{X}_{8}$ & Hizmet Ticareti (GSYH \%) & Kullanıld1 \\
\hline $\mathbf{X}_{9}$ & Reel Döviz Kuru İndeksi (2010=100 Dolar) & Kullanıldı \\
\hline $\mathbf{X}_{10}$ & Yaşayan Türk Nüfusu (20 bin ve üzeri) & Kullanıld 1 \\
\hline $\mathbf{X}_{11}$ & Nüfus (Say) & Kullanıld 1 \\
\hline $\mathbf{X}_{12}$ & Ortalama Ömür & Kullanıldı \\
\hline $\mathbf{X}_{13}$ & Doğum Sayısı & Kullanıld1 \\
\hline $\mathbf{X}_{14}$ & Ölüm Sayısı & Kullanıldı \\
\hline $\mathbf{X}_{15}$ & Kentleşme Oranı & Kullanıld 1 \\
\hline $\mathbf{X}_{16}$ & 65 Yaş Üstü Nüfus & Kullanıld1 \\
\hline $\mathbf{X}_{17}$ & Seyahat Hizmetleri (Hizmet İthalatının \%’si) & Kullanıld1 \\
\hline $\mathbf{X}_{18}$ & Uluslararası Seyahat Eşyası Harcamaları (Dolar) & Kullanıld 1 \\
\hline $\mathbf{X}_{19}$ & Ulaştırma Hizmetleri (Hizmet İthalatının \%’si) & Kullanıld 1 \\
\hline $\mathbf{X}_{20}$ & Uluslararası Turizm (Sayı, Gelenler) & Kullanıld1 \\
\hline $\mathbf{X}_{21}$ & Havayolu Taşımacılığı & Kullanıldı \\
\hline $\mathbf{X}_{22}$ & İletişim Bilgisayar vb. (Hizmet İhracatının \%’si) & Kullanıld 1 \\
\hline $\mathbf{X}_{23}$ & İnternet Kullanan Bireyler (Nüfusun \%’si & Kullanıldı \\
\hline $\mathbf{X}_{24}$ & İletişim Bilgisayar vb. (Hizmet İthalatının \%’si) & Kullanıld1 \\
\hline- & Enflasyon Oranı & Veri Uyumsuzluğu (Kullanılmadı) \\
\hline- & Uluslararası Turizm Kalkış (Sayı) & Veri Uyumsuzluğu (Kullanılmadı) \\
\hline- & ARGE Harcamaları (GSYH \%'si) & Veri Uyumsuzluğu (Kullanılmadı) \\
\hline- & Türkiye’ye Karayolu Uzaklığı & Çoklu Doğrusal Bağlantı Sorunu (Kullanılmadı) \\
\hline- & Gelişmişlik Seviyesi & Çoklu Doğrusal Bağlantı Sorunu (Kullanılmadı) \\
\hline- & Vize Uygulaması & Çoklu Doğrusal Bağlantı Sorunu (Kullanılmadı) \\
\hline- & Dini İnanç & Çoklu Doğrusal Bağlantı Sorunu (Kullanılmadı) \\
\hline- & Türkiye ile Tarihi Yakınlık & Çoklu Doğrusal Bağlantı Sorunu (Kullanılmadı) \\
\hline- & Türkiye ile Tarihi Benzerlik & Çoklu Doğrusal Bağlantı Sorunu (Kullanılmadı) \\
\hline- & Tarihi Önem & Çoklu Doğrusal Bağlantı Sorunu (Kullanılmadı) \\
\hline- & Resmi Dil & Çoklu Doğrusal Bağlantı Sorunu (Kullanılmadı) \\
\hline- & İklim & Çoklu Doğrusal Bağlantı Sorunu (Kullanılmadı) \\
\hline- & Komşuluk & Çoklu Doğrusal Bağlantı Sorunu (Kullanılmadı) \\
\hline- & Siyasi Konjonktür & Çoklu Doğrusal Bağlantı Sorunu (Kullanılmadı) \\
\hline- & Türkiye’ye Havayolu Uzaklığı & Çoklu Doğrusal Bağlantı Sorunu (Kullanılmadı) \\
\hline- & Tüketici Fiyat Endeksi $(2010=100)$ & Çoklu Doğrusal Bağlantı Sorunu (Kullanılmadı) \\
\hline- & Uluslararası Turizm Harcamaları (Dolar) & Çoklu Doğrusal Bağlantı Sorunu (Kullanılmadı) \\
\hline
\end{tabular}

$\mathrm{Bu}$ bağlamda Bağımlı değişken olan Milliyetlerine göre Türkiye'ye gelen turist sayısı ile bağımsız değişkenler arasındaki bağıntı aşağıdaki regresyon denklemi (modeli) ile verilmiştir.

$\mathrm{Y}$ it $=\alpha+\beta 1$ X1it $+\beta 2$ X2ci $+\beta 3$ X3it $+\beta 4$ X4it $+\beta 5$ X5it $+\beta 6$ X6it $+\beta 7$ X7it $+\beta 8$ X8it $+\beta 9$ X9it + $\beta 10$ X10it $+\beta 11$ X11it $+\beta 12$ X12it $+\beta 13$ X13it $+\beta 14$ X14it $+\beta 15$ X15it $+\beta 16$ X16it $+\beta 17$ X17it + $\beta 18$ X18it $+\beta 19$ X19it $+\beta 20$ X20it $+\beta 21$ X21it $+\beta 22$ X22it $+\beta 23$ X23it $+\beta 24$ X24ct + vi + eit

Araştırmanın analiz sürecini araştırma soruları belirlemiştir. Bu bağlamda araştırmanın dört adet ana sorusu ve bu ana soruların da 24 adet alt sorusu bulunmaktadır. Araştırmadaki ana sorular aşağıda verilmektedir;

Ana Soru 1: Avrupa ülkelerinin ekonomik yapıları Türkiye'ye yönelik turizm talebini nasıl ve ne yönde etkilemektedir?

Ana Soru 2: Avrupa ülkelerinin sosyo-demografik yapıları Türkiye'ye yönelik turizm talebini nasıl ve ne yönde etkilemektedir? 
Ana Soru 3: Avrupa ülkelerinin turizm ve seyahat yapıları (özellikleri) Türkiye’ye yönelik turizm talebini nas1l ve ne yönde etkilemektedir?

Ana Soru 4: Avrupa ülkelerinin teknolojik yapıları Türkiye’ye yönelik turizm talebini nasıl ve ne yönde etkilemektedir?

Araştırmada verilerin analiz edilmesinde panel veri analizi kullanılmış ve Stata 14.2 programından yararlanılmıştır. Yatay kesit verisinin zaman boyutundan küçük olması araştırmada kullanılan panelin kısa panel (Tarı, 2016: 475) (41 değiş̧ken>26 yıl) olduğu göstermektedir. Zaman serisinin içerisinde değişkenler arasındaki gözlemlerde (veri eksikliği) farklılık söz konusudur (Tatoğlu, 2016: 5). Araştırma kapsamında oluşturulan panelin dengesiz panel olduğu söylenebilir. Çalışma kapsamında Türkiye'ye yönelik turizm talebini etkileyen faktörlerin belirlenmesinde çoklu regresyondan faydalanılmış ve doğrusal panel veri modellerinin test edilmesinde kullanılan modellerden olan sıradan en küçük kareler, sabit etkiler ve rassal (tesadüfi) etkiler modellerinden yararlanılmıştır.

\section{BULGULAR}

Araştırmanın bu bölümünde Avrupa'dan Türkiye'ye yönelik turizm talebini etkileyen faktörlerin tespitine ilişkin bulgular yer almaktadır. Avrupa için Batı Avrupa ve Avrupa Birliği olmak üzere üç farklı ülke grubu için elde edilen veriler dengesiz panel olarak bir veri tabanına aktarılmıştır. 26 yıllık verileri kapsayan bu panel veri analizi sayesinde Türkiye'ye yönelik turizm talebini etkileyen faktörler iki farklı Avrupa grubu için analiz edilmiş ve kısımda bunlar raporlanmıştır. Faktörlere ilişkin tahminler "en küçük kareler, sabit etkiler ve rassal etkiler modellerinin her biri için yapılmıştır. Daha sonra modellere ait istatistiksel ön görüler dikkate alınarak hangi yöntemin kullanılacağına karar verilmiştir.

Tablo 2. AB'nin Betimleyici İstatistikleri

\begin{tabular}{|c|c|c|c|c|c|}
\hline Değişken & $\mathbf{N}$ & Aritmetik Otalama & Standart Sapma & Min. Değer & Maksi. Değer \\
\hline GSYH & 746 & $4.93 \mathrm{e}+11$ & $7.75 \mathrm{e}+11$ & $6.52 \mathrm{e}+08$ & $3.89 \mathrm{e}+12$ \\
\hline Harc. MG & 688 & 21288.79 & 17353.73 & -9.753427 & 82019.95 \\
\hline Büyüme Oranı & 640 & 2.8178 & 5.629952 & -28.93297 & 33.7 \\
\hline Gini Katsayısı & 320 & 308.5613 & 4967.265 & 23.7 & 88888 \\
\hline İstihdam & 754 & 8556454 & $1.04 \mathrm{e}+07$ & 147806 & $4.35 e+07$ \\
\hline İşsizlik & 754 & 10.2634 & 7.161369 & 1.8 & 37.25 \\
\hline Gider & 669 & 36.11511 & 7.90885 & 15.95481 & 62.24209 \\
\hline Hizmet Ticareti & 692 & 26.51293 & 34.28873 & 5.476721 & 301.3771 \\
\hline Reel Döviz Kuru & 731 & 97.49596 & 15.48051 & 41.12562 & 152.4943 \\
\hline Türk Nüfusu & 754 & 0.5172414 & 0.5000343 & 0 & 1 \\
\hline Nüfus & 754 & $1.75 \mathrm{e}+07$ & $2.17 \mathrm{e}+07$ & 414 & $8.27 e+07$ \\
\hline Ortalama Ömür & 754 & 77.40981 & 3.173045 & 69.4 & 83.5 \\
\hline Doğum Sayı1s1 & 754 & 167979.8 & 219275.6 & 6 & 812553 \\
\hline Ölüm Sayısı & 754 & 154853.8 & 201299 & 39 & 898246 \\
\hline Kentleşme & 753 & 68.85007 & 13.58855 & 37.25 & 97.9 \\
\hline $65+$ Nüfus & 754 & 2913174 & 3931409 & 28468 & $1.77 \mathrm{e}+07$ \\
\hline Turist Say1s1 & 714 & 405398.3 & 754399 & 1105 & 5580792 \\
\hline Seyahat Hizmetleri & 673 & 25.73671 & 11.51515 & 1.346801 & 76.87146 \\
\hline Seyahat Eşyası Harcaması & 664 & $1.08 \mathrm{e}+10$ & $1.72 \mathrm{e}+10$ & 5000000 & $9.33 \mathrm{e}+10$ \\
\hline Ulaştırma Hizmetleri & 659 & 25.39266 & 11.04258 & 0.287464 & 57.98066 \\
\hline Uluslararası turizm & 664 & $1.21 \mathrm{e}+10$ & $1.98 \mathrm{e}+10$ & $1.30 \mathrm{e}+07$ & $1.06 \mathrm{e}+11$ \\
\hline Havayolu Taşımacılığı & 690 & $1.76 e+07$ & $2.76 e+07$ & 644.1 & $1.54 \mathrm{e}+08$ \\
\hline İletişim bilgisayar (ihracat) & 674 & 37.04377 & 22.78054 & -379.717 & 74.61359 \\
\hline İnternet Kullanan Bireyler & 733 & 43.5383 & 33.01782 & .002339 & 98.24002 \\
\hline İletişim bilgisayar (ithalat) & 659 & 41.23348 & 13.69339 & 6.778477 & 82.75012 \\
\hline
\end{tabular}

Tablo 2'de AB'nin Türkiye'ye yönelik turizm talebinin betimleyici istatistikleri yer almaktadır. İlgili bölgeye ait veri tabanında veri işlenmiş maksimum gözlem sayısının 754 olduğu anlaşılmaktadır. Ayrıca 
sosyo-demografik değerler başta olmak üzere çok sayıda değişkenin bütün gözlem değerleri için verilerin işlendiği görülmektedir. 1992-2017 zaman periyodunda Avrupa Birliğinden Türkiye’ye gelen turistlerin ortalaması 405398.3 'tür. Bu sayı bütün ülke gruplarını içine olan genel değerlendirmenin iki katına yakındır.

Söz konusu bölge için kentleşme oranı ortalaması \%68 seviyelerindedir. Ayrıca bütün ülkeler için ilgili tarih aralığında işlenmiş maksimum turist sayısı 5 milyon 580 bin sevilerinde, minimum sayı ise 1.105 'tir. Araştırmaya göre AB'de de internet kullanan bireylerin ortalamaması yaklaşı \% $\% 43,5$ seviyelerindedir. Tablo 5.3'e göre Avrupa birliğinin iletişim ve bilgisayar vb. harcamaları hizmet ithalatının ortalama \%41'i iken, iletişim ve bilgisayar vb. gelirleri hizmet ihracatının ortalama \%37'si civarındadır.

Batı Avrupa, AB’ye göre daha dar bir bölge olup, daha fazla gelişmiş devleti barındıran bir ülke grubudur. Bu değerlendirmenin Türkiye'ye yönelik talebi etkileyen faktörlere yansımalarının da olacağı düşünülmektedir. Tablo 3'te Batı Avrupa bölgesinin Türkiye'ye yönelik turizm talebinin betimleyici istatistikleri yer almaktadır. Bölge için veri işlenen toplam maksimum gözlem sayısı 546'dır. Bölgeden Türkiye'ye gelen turistlerin ortalaması 26 yıllık dönem için 453408.3'tür. Bu daha önce işlenen AB ülkelerinin talebinden ortalama olarak daha yüksektir. 0,57'lik ortalama ile bölgede yaşayan Türk nüfusun yaşamayan ülkelere kıyasla çoğunlukta olduğu söylenebilir.

Tablo 3. Batı Avrupa'nın Betimleyici Istatistikleri

\begin{tabular}{|c|c|c|c|c|c|}
\hline Değişken & $\mathbf{N}$ & Aritmetik Otalama & Standart Sapma & Min. Değer & Maksi. Değer \\
\hline GSYH & 546 & $6.59 \mathrm{e}+11$ & $8.47 e+11$ & $6.13 e+09$ & $3.89 e+12$ \\
\hline Harc. MG & 500 & 27180.22 & 16685.33 & -9.753427 & 82019.95 \\
\hline Büyüme Oranı & 486 & 2.893922 & 6.060619 & -28.93297 & 33.7 \\
\hline Gini Katsayısı & 249 & 387.6502 & 5631.098 & 24.9 & 88888 \\
\hline İstihdam & 546 & $1.07 \mathrm{e}+07$ & $1.14 \mathrm{e}+07$ & 147806 & $4.35 \mathrm{e}+07$ \\
\hline İşsizlik & 546 & 7.928908 & 4.428021 & 1.8 & 27.47 \\
\hline Gider & 517 & 36.81372 & 8.166532 & 15.95481 & 62.24209 \\
\hline Hizmet Ticareti & 501 & 28.76126 & 39.78613 & 7.898113 & 301.3771 \\
\hline Reel Döviz Kuru & 546 & 97.94689 & 12.4369 & 43.90381 & 152.4943 \\
\hline Türk Nüfusu & 546 & 0.5714286 & 0.4953255 & 0 & 1 \\
\hline Nüfus & 546 & $2.18 \mathrm{e}+07$ & $2.39 \mathrm{e}+07$ & 414 & $8.27 \mathrm{e}+07$ \\
\hline Ortalama Ömür & 546 & 78.54615 & 2.649271 & 69.4 & 83.5 \\
\hline Doğum Sayısı & 546 & 209622.9 & 242603.5 & 6 & 812553 \\
\hline Ölüm Sayısı & 546 & 189093.7 & 222477 & 39 & 898246 \\
\hline Kentleşme & 545 & 74.57128 & 10.31004 & 49.13 & 97.9 \\
\hline $65+$ Nüfus & 546 & 3686679 & 4343671 & 28468 & $1.77 \mathrm{e}+07$ \\
\hline Turist Say1s1 & 546 & 453408.3 & 825514 & 1105 & 5580792 \\
\hline Seyahat Hizmetleri & 481 & 24.88291 & 9.518279 & 3.192168 & 51.7113 \\
\hline Seyahat Eşyası Harcaması & 483 & $1.45 \mathrm{e}+10$ & $1.88 \mathrm{e}+10$ & $2.82 \mathrm{e}+08$ & $9.33 \mathrm{e}+10$ \\
\hline Ulaştırma Hizmetleri & 467 & 23.77003 & 10.797 & .287464 & 54.51021 \\
\hline Uluslararası turizm & 483 & $1.63 \mathrm{e}+10$ & $2.17 \mathrm{e}+10$ & $2.82 \mathrm{e}+08$ & $1.06 \mathrm{e}+11$ \\
\hline Havayolu Taşımacılığı & 507 & $2.36 \mathrm{e}+07$ & $2.99 \mathrm{e}+07$ & 460600 & $1.54 \mathrm{e}+08$ \\
\hline İletişim bilgisayar (ihracat) & 482 & 39.01089 & 15.18966 & 0.3163742 & 74.61359 \\
\hline İnternet Kullanan Bireyler & 542 & 47.79101 & 33.90539 & 0.0482916 & 98.24002 \\
\hline İletişim bilgisayar (ithalat) & 467 & 42.95896 & 12.94148 & 14.22855 & 82.75012 \\
\hline
\end{tabular}

Bölge ülkeleri arasında kentleşme ortalama \%77, ortalama ömür ise 78 seviyelerindedir. Bu iki ortalama değer de daha önce ele alınan $\mathrm{AB}$ ülke grubuna göre daha yüksektir. Bu iki ülke grubuna göre yüksek çıkan ve önemli kabul edilen diğer bir ortalama değer ise internet kullanan bireylerin oranıdır. Bölgede günümüzde nüfusun nerdeyse tamamına yakını internet kullanabilmektedir. Ayrıca bölge genelinde 
yaklaşık 3,6 milyon 65 yaş üstü nüfus yaşamaktadır. Bölgede ortalama yıllık büyüme oranı yaklaşık $\% 2,8$ iken, işsizlik oranı ortalama $\% 8$ civarındadır.

Tablo 4. AB'nin Türkiye'ye Yönelik Turizm Talebinin Regresyon Sonuçları

\begin{tabular}{|c|c|c|c|c|c|c|}
\hline \multirow{3}{*}{ Değişkenler } & \multicolumn{3}{|c|}{ Batı Avrupa } & \multicolumn{3}{|c|}{ Avrupa Birliği } \\
\hline & (1) & (2) & (3) & (1) & (2) & (3) \\
\hline & $\begin{array}{c}\text { En Küçük } \\
\text { Kareler }\end{array}$ & $\begin{array}{c}\text { Sabit } \\
\text { Etkiler }\end{array}$ & $\begin{array}{l}\text { Rassal } \\
\text { Etkiler }\end{array}$ & $\begin{array}{c}\text { En Küçük } \\
\text { Kareler }\end{array}$ & Sabit Etkiler & $\begin{array}{l}\text { Rassal } \\
\text { Etkiler }\end{array}$ \\
\hline GSYH & $\begin{array}{l}-2.24 \mathrm{e}-07 \\
(1.79 \mathrm{e}-07)\end{array}$ & $\begin{array}{l}-2.51 \mathrm{e}-08 \\
(2.14 \mathrm{e}-07)\end{array}$ & $\begin{array}{l}-2.24 \mathrm{e}-07 \\
(1.79 \mathrm{e}-07)\end{array}$ & $\begin{array}{c}-8.85 \mathrm{e}-08 \\
(1.73 \mathrm{e}-07)\end{array}$ & $\begin{array}{c}1.80 \mathrm{e}-07 \\
(2.07 \mathrm{e}-07)\end{array}$ & $\begin{array}{l}-8.85 \mathrm{e}-08 \\
(1.73 \mathrm{e}-07)\end{array}$ \\
\hline Kişi Harcanabilir MG & $\begin{array}{l}-2.148 \\
(2.852)\end{array}$ & $\begin{array}{l}-1.815 \\
(5.933)\end{array}$ & $\begin{array}{l}-2.148 \\
(2.852)\end{array}$ & $\begin{array}{c}-6.828 * * * \\
(2.558)\end{array}$ & $\begin{array}{l}-6.274 \\
(5.327)\end{array}$ & $\begin{array}{c}-6.828 * * * \\
(2.558)\end{array}$ \\
\hline Büyüme Oranı & $\begin{array}{c}-11,266^{* * * *} \\
(3,254)\end{array}$ & $\begin{array}{l}-2,128 \\
(6,954)\end{array}$ & $\begin{array}{c}-11,266^{* * * *} \\
(3,254)\end{array}$ & $\begin{array}{l}-5,595^{*} \\
(3,065)\end{array}$ & $\begin{array}{c}3,258 \\
(5,483)\end{array}$ & $\begin{array}{l}-5,595^{*} \\
(3,065)\end{array}$ \\
\hline Gini katsayısı & $\begin{array}{c}1.420 \\
(2.064)\end{array}$ & $\begin{array}{c}1.432 \\
(1.997)\end{array}$ & $\begin{array}{c}1.420 \\
(2.064)\end{array}$ & $\begin{array}{c}1.086 \\
(2.219)\end{array}$ & $\begin{array}{c}1.631 \\
(2.068)\end{array}$ & $\begin{array}{l}1.086 \\
(2.219)\end{array}$ \\
\hline İstihdam & $\begin{array}{c}0.252 * * * \\
(0.0291)\end{array}$ & $\begin{array}{l}0.0414 \\
(0.158)\end{array}$ & $\begin{array}{c}0.252 * * * \\
(0.0291)\end{array}$ & $\begin{array}{c}0.212 * * * \\
(0.0249)\end{array}$ & $\begin{array}{c}0.0822 \\
(0.0828)\end{array}$ & $\begin{array}{c}0.212 * * * \\
(0.0249)\end{array}$ \\
\hline İşsizlik & $\begin{array}{c}25,149 * * * * \\
(8,281)\end{array}$ & $\begin{array}{c}13,753 \\
(12,359)\end{array}$ & $\begin{array}{c}25,149 * * * \\
(8,281)\end{array}$ & $\begin{array}{c}-24,162^{* * * *} \\
(5,293)\end{array}$ & $\begin{array}{c}9,921 \\
(10,650)\end{array}$ & $\begin{array}{c}-24,162 * * * \\
(5,293)\end{array}$ \\
\hline Gider & $\begin{array}{c}2,929 \\
(4,026)\end{array}$ & $\begin{array}{l}-2,953 \\
(6,951)\end{array}$ & $\begin{array}{c}2,929 \\
(4,026)\end{array}$ & $\begin{array}{l}-2,886 \\
(2,906)\end{array}$ & $\begin{array}{l}-2,192 \\
(5,861)\end{array}$ & $\begin{array}{l}-2,886 \\
(2,906)\end{array}$ \\
\hline Hizmet ticareti & $\begin{array}{l}2,403^{*} \\
(1,317)\end{array}$ & $\begin{array}{l}-689.9 \\
(3,106)\end{array}$ & $\begin{array}{l}2,403^{*} \\
(1,317)\end{array}$ & $\begin{array}{c}2,481 * * * \\
(946.9)\end{array}$ & $\begin{array}{l}-1,217 \\
(3,093)\end{array}$ & $\begin{array}{c}2,481 * * * \\
(946.9)\end{array}$ \\
\hline Reel Döviz Kuru & $\begin{array}{l}-3,742 * \\
(2,062) \\
\end{array}$ & $\begin{array}{c}4,644 \\
(3,736) \\
\end{array}$ & $\begin{array}{l}-3,742 * \\
(2,062) \\
\end{array}$ & $\begin{array}{l}-458.1 \\
(1,965) \\
\end{array}$ & $\begin{array}{l}7,284 * * \\
(3,062) \\
\end{array}$ & $\begin{array}{l}-458.1 \\
(1,965) \\
\end{array}$ \\
\hline Türk Nüfusu & $\begin{array}{c}76,072 \\
(79,273)\end{array}$ & & $\begin{array}{c}76,072 \\
(79,273)\end{array}$ & $\begin{array}{c}118,132 * * \\
(47,670)\end{array}$ & $\begin{array}{l}- \\
-\end{array}$ & $\begin{array}{c}118,132 * * \\
(47,670)\end{array}$ \\
\hline Nüfus & $\begin{array}{c}-0.162 * * * \\
(0.0140)\end{array}$ & $\begin{array}{c}-0.111 \\
(0.0781)\end{array}$ & $\begin{array}{c}-0.162 * * * \\
(0.0140)\end{array}$ & $\begin{array}{c}-0.154 * * * \\
(0.0132)\end{array}$ & $\begin{array}{c}-0.146 * * \\
(0.0610)\end{array}$ & $\begin{array}{c}-0.154 * * * \\
(0.0132)\end{array}$ \\
\hline Ortalama Ömür & $\begin{array}{c}1,432 \\
(14,898)\end{array}$ & $\begin{array}{c}-155,804 * * * \\
(54,552)\end{array}$ & $\begin{array}{c}1,432 \\
(14,898)\end{array}$ & $\begin{array}{l}-14,395 \\
(11,145)\end{array}$ & $\begin{array}{c}-191,949 * * * \\
(46,517)\end{array}$ & $\begin{array}{l}-14,395 \\
(11,145)\end{array}$ \\
\hline Doğum Sayısı & $\begin{array}{l}0.0662 \\
(0.112)\end{array}$ & $\begin{array}{c}-0.00666 \\
(0.106)\end{array}$ & $\begin{array}{l}0.0662 \\
(0.112)\end{array}$ & $\begin{array}{l}0.0576 \\
(0.120)\end{array}$ & $\begin{array}{c}-0.00143 \\
(0.108)\end{array}$ & $\begin{array}{l}0.0576 \\
(0.120)\end{array}$ \\
\hline Ölüm Sayıs1 & $\begin{array}{c}0.399 * * * \\
(0.129)\end{array}$ & $\begin{array}{c}0.261 * * \\
(0.121)\end{array}$ & $\begin{array}{c}0.399 * * * \\
(0.129)\end{array}$ & $\begin{array}{c}0.414 * * * \\
(0.137)\end{array}$ & $\begin{array}{l}0.228^{*} \\
(0.123)\end{array}$ & $\begin{array}{c}0.414 * * * \\
(0.137)\end{array}$ \\
\hline Kentleşme & $\begin{array}{l}-2,511 \\
(3,236)\end{array}$ & $\begin{array}{c}48,273 * * \\
(18,467)\end{array}$ & $\begin{array}{l}-2,511 \\
(3,236)\end{array}$ & $\begin{array}{c}262.5 \\
(2,134)\end{array}$ & $\begin{array}{c}54,032 * * * \\
(16,063)\end{array}$ & $\begin{array}{c}262.5 \\
(2,134)\end{array}$ \\
\hline $65+$ Nüfus & $\begin{array}{c}0.299 * * * \\
(0.0426) \\
\end{array}$ & $\begin{array}{c}0.330 * * * \\
(0.100)\end{array}$ & $\begin{array}{c}0.299 * * * \\
(0.0426) \\
\end{array}$ & $\begin{array}{c}0.331 * * * \\
(0.0436) \\
\end{array}$ & $\begin{array}{c}0.347 * * * \\
(0.0882) \\
\end{array}$ & $\begin{array}{c}0.331 * * * \\
(0.0436) \\
\end{array}$ \\
\hline Seyahat Hizmetleri & $\begin{array}{c}-11,447 * * * \\
(3,342)\end{array}$ & $\begin{array}{l}-4,023 \\
(5,869)\end{array}$ & $\begin{array}{c}-11,447 * * * \\
(3,342)\end{array}$ & $\begin{array}{c}-4,675^{* *} * \\
(2,242)\end{array}$ & $\begin{array}{l}6,840^{*} \\
(3,660)\end{array}$ & $\begin{array}{c}-4,675^{* *} \\
(2,242)\end{array}$ \\
\hline $\begin{array}{l}\text { Uluslararası Seyahat Eşyası } \\
\text { Harcaması }\end{array}$ & $\begin{array}{c}0.000145^{* * *} \\
(2.16 \mathrm{e}-05)\end{array}$ & $\begin{array}{l}7.79 \mathrm{e}-05^{* *} \\
(3.11 \mathrm{e}-05)\end{array}$ & $\begin{array}{l}0.000145^{* * *} * \\
(2.16 \mathrm{e}-05)\end{array}$ & $\begin{array}{c}0.000174 * * * \\
(2.11 \mathrm{e}-05)\end{array}$ & $\begin{array}{l}5.66 \mathrm{e}-05^{*} \\
(3.14 \mathrm{e}-05)\end{array}$ & $\begin{array}{c}0.000174 * * * \\
(2.11 \mathrm{e}-05)\end{array}$ \\
\hline Ulaştırma Hizmetleri & $\begin{array}{c}7,932 * * * \\
(2,794)\end{array}$ & $\begin{array}{c}10,571 * * \\
(4,728)\end{array}$ & $\begin{array}{c}7,932 * * * \\
(2,794)\end{array}$ & $\begin{array}{c}2,854 \\
(2,473)\end{array}$ & $\begin{array}{c}406.5 \\
(3,543)\end{array}$ & $\begin{array}{c}2,854 \\
(2,473)\end{array}$ \\
\hline Uluslararası Turizm (Gelenler) & $\begin{array}{c}-9.76 \mathrm{e}-05^{* * *} * \\
(1.98 \mathrm{e}-05)\end{array}$ & $\begin{array}{c}-5.85 \mathrm{e}-05^{* *} \\
(2.49 \mathrm{e}-05)\end{array}$ & $\begin{array}{l}-9.76 \mathrm{e}-05^{* * * *} \\
(1.98 \mathrm{e}-05)\end{array}$ & $\begin{array}{c}-0.000125^{* * * *} \\
(1.98 \mathrm{e}-05)\end{array}$ & $\begin{array}{c}-5.17 \mathrm{e}-05^{* *} \\
(2.53 \mathrm{e}-05)\end{array}$ & $\begin{array}{c}-0.000125 * * * \\
(1.98 \mathrm{e}-05)\end{array}$ \\
\hline Havayolu Taşımacılığı & $\begin{array}{l}0.000162 \\
(0.00220) \\
\end{array}$ & $\begin{array}{c}0.0194 * * * \\
(0.00727)\end{array}$ & $\begin{array}{l}0.000162 \\
(0.00220)\end{array}$ & $\begin{array}{c}0.00183 \\
(0.00226) \\
\end{array}$ & $\begin{array}{c}0.0216^{* * * *} \\
(0.00695)\end{array}$ & $\begin{array}{c}0.00183 \\
(0.00226)\end{array}$ \\
\hline İletişim Bilgisayar vb. (İhracat) & $\begin{array}{c}929.4 \\
(2,649)\end{array}$ & $\begin{array}{l}-472.7 \\
(2,795)\end{array}$ & $\begin{array}{c}1,403 \\
(1,567)\end{array}$ & $\begin{array}{l}-751.1 \\
(2,011)\end{array}$ & $\begin{array}{l}-1,670 \\
(2,378)\end{array}$ & $\begin{array}{l}-751.1 \\
(2,011)\end{array}$ \\
\hline İnternet Kullana Bireyler & $\begin{array}{c}584.4 \\
(1,154)\end{array}$ & $\begin{array}{c}3,948 * * \\
(1,925)\end{array}$ & $\begin{array}{c}2,451 * * * \\
(821.7)\end{array}$ & $\begin{array}{c}1,311 \\
(956.3)\end{array}$ & $\begin{array}{c}6,316^{* * * *} \\
(1,805)\end{array}$ & $\begin{array}{c}1,311 \\
(956.3)\end{array}$ \\
\hline İletişim Bilgisayar vb. (İthalat) & $\begin{array}{l}5,670 * \\
(3,211)\end{array}$ & $\begin{array}{l}7,481 * \\
(4,061)\end{array}$ & $\begin{array}{c}6,077 * * * \\
(1,918)\end{array}$ & $\begin{array}{c}3,645 \\
(2,357)\end{array}$ & $\begin{array}{c}864.8 \\
(3,280) \\
\end{array}$ & $\begin{array}{c}3,645 \\
(2,357)\end{array}$ \\
\hline Sabit & $\begin{array}{c}-180,720 \\
(1.160 \mathrm{e}+06)\end{array}$ & $\begin{array}{c}8.229 \mathrm{e}+06 * * \\
(3.832 \mathrm{e}+06)\end{array}$ & $\begin{array}{c}-180,720 \\
(1.160 \mathrm{e}+06)\end{array}$ & $\begin{array}{c}925,077 \\
(774,047) \\
\end{array}$ & $\begin{array}{c}1.095 \mathrm{e}+07 * * * \\
(3.161 \mathrm{e}+06)\end{array}$ & $\begin{array}{c}925,077 \\
(774,047) \\
\end{array}$ \\
\hline Gözlemler & 170 & 170 & 170 & 195 & 195 & 195 \\
\hline $\mathrm{R}^{2}$ & 0.963 & 0.834 & 0.963 & 0.950 & 0.805 & 0.950 \\
\hline Siralama & 18 & 18 & 18 & 25 & 25 & 25 \\
\hline
\end{tabular}

Tablo 4 Avrupa Birliği ve Batı Avrupa ülkelerinden Türkiye’ye yönelik olan turizm talebini etkileyen faktörlere ilişkin üç model için regresyon ve anlamlılık değerlerini içermektedir. Hangi modelin kullanılacağı ile ilgili ilk olarak Breusch-Pagan LM testi yapılmış ve "H0: Birim etkinin varyansı sıfıra eşittir." hipotezi test edilmiştir. LM testi sonucunda hipotez kabul edilmiş (prob $>$ chi $2=1,0000>0,05$ ) ve en küçük kareler (OLS) modelinin tahmin için en uygun model olduğuna karar verilmiştir. Bu nedenle her iki ülke grubu için de değerlendirmeler OLS modeli üzerinden yapılmaktadır. Tablo 4'te AB ve Batı 
Avrupa regresyon modellerinin aynı tabloda verilerek karılaştırma yapılmasında kolaylık sağlanmaya çalışılmıştır.

Avrupa Birliği ülkelerinin ekonomik değişkenlerinden kişi başı harcanabilir gelir, işsizlik oranı ve yıllık büyüme oranı Türkiye turizm talebini negatif olarak etkilerken, istihdam ve hizmet ticareti pozitif olarak etkilemektedir. Batı Avrupa ülkeleri için ekonomik değişkenlerden yıllık büyüme oranı ve reel döviz kuru ile Türkiye turizm talebi arasında negatif ilişki söz konusu iken, istihdam, işsizlik ve hizmet ticareti ile ülkenin turizm talebi arasında pozitif ilişki söz konusudur. Bu değişkenlere ait etkiler \%90, 95 ve 99 güven aralıklarında gerçekleşmektedir. $\mathrm{AB}$ ülkelerinde işsizlik bir birim arttığında, Türkiye'ye yönelik turizm talebi 24,1 birim azalmaktadır. Aynı şekilde, kişi başı harcanabilir gelirde meydana gelen bir birimlik artış, ülkenin turizm talebinde 6,8 birimlik bir azalmaya sebep olmaktadır. Bunun yanında; $A B$ ülkelerinde hizmet ticaretinde oluşacak bir birimlik artış, Türkiye'nin turizm talebini 2,4 birim arttırmaktadır. Batı Avrupa ülkelerinde istihdam bir birim arttığında bu ülkelerden Türkiye'ye yönelik turizm talebi 0,25 birim, hizmet ticareti bir birim arttı̆̆ında ise 2,4 birim artmaktadır. Buna karşın, reel döviz kuru bir birim arttığında ilgili ülkelerden Türkiye'ye yönelik talep 3,7 birim azalmaktadır. Bu sonuçlar Biçen (2004) ile Demirel ve arkadaşları (2013) tarafından yapılan araştırmaların sonuçları ile de benzerlik göstermektedir.

$\mathrm{AB}$ ülkeleri ile ilgili sosyo-demografik değişkenlerden ülkede yaşayan Türk nüfusunun olması, toplam ülke nüfusu, ölüm sayısı ve 65 yaş üstü nüfus değişkenleri Türkiye'ye yönelik turizm talebi ile ilişkisi olan değişkenler olmuştur. Batı Avrupa ülke grubu için sosyo-demografik değişkenlerden nüfus (negatif), ölüm sayısı (pozitif) ve 65 yaş üstü nüfus (pozitif) değişkenlerinin üçü de Türkiye'ye yönelik turizm talebini etkilemektedir. Bu değişkenler ait etkiler $\% 95$ ve 99 güven aralıklarında gerçekleşmektedir. Örneğin $\mathrm{AB}$ 'de 65 yaş üstü nüfusta meydana gelebilecek bir birimlik artış Türkiye'nin turizm talebinde 0,33 'lük bir artışı beraberinde getirmektedir.

Avrupa birliği ülkelerinden turizm ve seyahatle ilgili olan değişkenlerden seyahat hizmetleri ve uluslararası turizm ile Türkiye'ye yönelik turizm talebi arasında negatif bir ilişki tespit edilirken, uluslararası seyahat eşyası harcaması değişkeni ile pozitif bir ilişki tespit edilmiştir. Batı Avrupa'dan ise Türkiye'ye yönelik turizm talebini seyahat hizmetleri ve uluslararası turizm değişkenleri negatif etkilerken, uluslararası seyahat eşyası harcaması ve ulaştırma hizmetleri pozitif etkilemektedir. $\mathrm{Bu}$ değişkenler ait etkiler $\% 95$ ve 99 güven aralıklarında gerçekleşmektedir. Örneğin ulaştırma hizmetlerinde meydana gelen bir birimlik artış ülkeye olan turizm talebinde 7,9 birimlik bir artış meydana getirmektedir. Teknolojik değişkenler Avrupa Birliğinden Türkiye'ye olan talebini etkilemezken, Batı Avrupa ülkelerinden ise sadece iletişim ve bilgisayar harcamaları \%90 güven aralığında Türkiye'ye yönelik turizm talebini pozitif olarak etkilemiş̧ir. Ayrıca Batı Avrupa ülke grubu bağlamında en küçük kareler modeli için model açıklayıcılığını gösteren $\mathrm{R}^{2}$ değeri \%96,3 iken, $\mathrm{AB}$ ülke grubu için $\% 95$ seviyelerindedir.

\section{SONUÇ VE DEĞERLENDİRME}

Öncellikle etkinin yönü ve şiddeti değişmekle birlikte, Avrupa Birliği ve Batı Avrupa ülkelerinden Türkiye'ye yönelik turizm talebinin test edilen değişken grupları arasında en çok ekonomik değişkenlere duyarlı bir görüntü sergilediği görülmektedir. Bunun yanında, ilgili ülkelerden Türkiye'ye yönelik talebinde en az belirleyici olan değişken grubu teknolojidir.

$\mathrm{AB}$ ülkelerinden Türkiye'ye yönelik turizm talebini etkileyen ekonomik değişkenler ile ilgili ilginç sonuçlar elde edilmiştir. Öncellikle kişi başı harcanabilir gelir ve büyüme oranı Türkiye'ye yönelik turizm talebi ile negatif bir ilişki içerisindedir. Bu durum daha önce de ifade edildiği gibi, harcanabilir gelir artışı ile büyüme olgusunun alternatif destinasyonları tercih etme gibi bir süreci de beraberinde getirdiği söylenebilir. Bunun yanı sıra ekonomik değişkenlerden beklenen sonuçları veren değişkenler de ortaya çıkmıştır. Örneğin istihdam ve hizmet ticareti Türkiye'ye yönelik turistik talebi olumlu etkilerken, işsizlik ve turizm talebi arasında beklendiği gibi negatif bir ilişki tespit edilmiştir.

AB ülkelerinde yaşayan Türk nüfusu, Türkiye'ye yönelik turizm talebini belirleyen önemli sosyodemografik değişken olarak ön plana çıkmıştır. AB'de yaşayan Türklerin turizm talebini teşvik edecek seviyede olumlu bir katkı sağladıkları ve bir bakıma gönüllü birer tanıtım elçisi ve ağızdan ağıza pazarlamanın Türkiye lehine birer uygulayıcısı gibi bir rol üstlendikleri söylenebilir. Turizm ve seyahat 
değişkenlerinden ön plana çıkan önemli değişkenlerin başında seyahat hizmetleri gelmektedir. Çünkü seyahat hizmetlerindeki artışın Türkiye'ye olan talebi pozitif olarak etkilemesi beklenirken, bu etki negatif yönde olmuştur. Ancak seyahat hizmetleri sadece turist göndermeyle ilgili bir kavram değil, ilgili ülkelerin turist çekme politika ve uygulamalarını da içermesi bu etkinin negatif olmasına aracılık etmiş olabilir. Nitekim durum bu şekilde değerlendirildiğinde, konu Türkiye'ye yönelik turizm talebiyle negatif ilişkisi tespit edilen uluslararası turizm değişkeninin sonuçları ile de örtüşmektedir.

Batı Avrupa, AB'nin de üyesi olan devletlerden oluşmaktadır. Ancak Batı Avrupa ülkeleri nispeten daha gelişmiş ülkelerden oluştuğundan, bu ülkelerden Türkiye'ye yönelik turizm talebini de etkileyen unsurlar farklıklar göstermektedir. Örneğin işsizlik AB bölgesi için Türkiye'ye yönelik talep ile negatif ilişki içerisindeyken, Batı Avrupa için bu ilişki pozitiftir.

Batı Avrupa ülkeleri için diğer ilginç bir sonuç da reel döviz kurunun Türkiye’ye yönelik turizm talebini negatif etkilemesidir. Yani reel döviz kuru yükseldikçe, bu bölgelerden Türkiye'ye yönelik turizm talebi düşmektedir. Bu olağan bir durumdur. Çünkü bu durumda ulusal para değer kaybetmekte, alım gücü düşmekte ve ileriye dönük beklentiler olumsuzlaşmaktadır. Hatta bu durumun en çok etkilediği alanların başında turizm ve seyahat gelir. Böyle durumlarda yurt dişı seyahat planlamalarında iptal veya ertelemeler dahi yaşanabilmektedir. İşsizlik Türkiye'ye Batı Avrupa'dan olan turizm hareketlerini pozitif etkilemektedir. Normalde negatif beklenen bu etkinin bazı ülke grupları için pozitif çıkması, ekonomik gelişmişlik ve sosyal refah ile açıklanabilir. Nitekim bu bölgedeki insanların refahı zaten yüksek olduğu için işsizlik seyahat etmelerine imkân sağlayacak boş zaman kavramına aracılık etmiş olabilir. Batı Avrupa'nın 27 bin doların üzerinde ortalama kişi başı harcanabilir milli gelir ile analizi yapılan bütün ülke grupları içerisindeki en yüksek gelire sahip olması da bunun bir göstergesi olarak ifade edilebilir.

Bilgilendirme / Acknowledgement:

Yazarlar aşağı daki billgillendirmeleri yapmaktadırlar:

1- Yazar(lar)ın Katkıları

ÜŞ: Çalışma fikrinin oluşturulması, verilerin toplanması ve tasnifi, kaynak taraması, sonuçların yorumlanması, makale yazımı ve yayınlama süreci;

BZ: Çalışmanın eleştirel incelemesi ve son okuması;

2-Bu çalışma Sakarya Uygulamalı Bilimler Üniversitesi Lisansüstü Eğitim Enstitüsünde sunulan “Türkiye'nin Turizm Talebini Etkileyen Faktörlerin Sosyo-Ekonomik Açıdan Ampirik Olarak Değerlendirilmesi" başlıklı doktora tezinden geliştirilmiştir.

3-Çalışmamız sırasında bize destek ve katkı sağlayan Dr. Öğr. Üyesi Mustafa Kenan ERKAN ve Arş. Gör. Abdüssamed KOÇ’a teşekkürlerimizi sunarız.

4- Bu araştırma için herhangi bir kamu kuruluşundan, özel veya kâr amacı gütmeyen sektörlerden hibe alınmamıştır.

5- Makalenin yazarları arasında çıkar çatışması bulunmamaktadır.

6- Makalemizde etik kurulu izni ve/veya yasal/özel izin alınmasını gerektiren bir durum yoktur. Çünkü çalışmada analiz edilen veriler açık erişimli resmi kurumlardan elde edilmiş istatistiklerdir.

7- Bu makalede araştırma ve yayın etiğine uyulmuştur.

\section{KAYNAKÇA}

Acaravcı, A. ve Bostancı, F. (2011). Makroekonomik değişkenlerin etkisinde yabancı yatırımlar üzerine etkileri: Türkiye ekonomisi için ampirik bir çalışma. Çă̆ Üniversitesi Sosyal Bilimler Dergisi, 8(2), 56-68

Akış, S. (1998). A compact econometric model of tourism demand for Turkey. Tourism Management, 19(1), 99-102.

Aktaş, C. (2005). Türkiye'nin turizm gelirini etkileyen değişkenler için en uygun regresyon denkleminin belirlenmesi. Doğuş Üniversitesi Dergisi, 6(2), 163-174. 
Alaeddinoğlu, F. (2006). Van Il'inin turizm potansiyelinin belirlenmesi ve planlamaya yönelik öneriler. Yayımlanmamış Doktora Tezi, Ankara Üniversitesi Sosyal Bilimler Enstitüsü, Ankara.

Atakan, T. (2008). İstanbul Menkul Kıymetler Borsası'nda haftanın günü etkisi ve ocak ayı anomalilerinin ARCH-GARCH modelleri ile test edilmesi. Istanbul University Journal of the School of Business Administration, 37(2), 98-110.

Avcıkurt, C. (2003). Turizm Sosyolojisi; Genel ve Yapısal Yaklaşım. Ankara: Detay Yayıncılık.

Aydın, A., Darıcı, B., ve Taşçı, H. (2015). Uluslararası turizm talebini etkileyen ekonomik faktörler: Türkiye üzerine bir uygulama. Erciyes Üniversitesi İktisadi ve İdari Bilimler Fakültesi Dergisi, (45), 143-177.

Biçen, S. (2004). Kur dalgalanmalarının dış turizm talebi üzerine etkileri. Yayımlanmamış yüksek lisans tezi, Uludağ Üniversitesi Sosyal Bilimler Enstitüsü, Bursa.

Crouch, G. (1995), A meta-analysis of tourism demand. Annals of Tourism Research, 22(1), 103-118.

Çımat, A. ve Bahar, O. (2003). Turizm sektörünün Türkiye ekonomisi içindeki yeri ve önemi. Akdeniz Üniversitesi İ.I.B.F Dergisi, (6), 1-18

Demirel, B., Alparslan, B., Bozdağ, E. G. ve İnci, A. G. (2013). The impact of exchange rate volatility on tourism sector: A case study, Turkey. Niğde Üniversitesi IIIBF Dergisi, 6(2), 117-126

Dritsakis, N. (2004). Cointegration analysis of German and british tourism demand for Greece. Tourism Management, 25, 111-119.

Dritsakis, N., \& Athanasiadis, S. (2000). An econometric model of tourist demand: The case of Greece. Journal of Hospitality \& Leisure Marketing, 7(2), 39-49.

Çeken, H., Ateşoğlu, L., Dalgın, T. ve Karadağ, L. (2018). Turizm talebine bağlı olarak uluslar aras1 turizm hareketlerindeki gelişmeler. Elektronik Sosyal Bilimler Dergisi, 7(26), 71-85

Gholipour, H. F., Tajaddini, R., ve Al-mulali, U. (2014). Does personal freedom influence outbound tourism? Tourism Management, 41, 19-25.

Görmüş, Ş., ve Göçer, İ. (2010). Türkiye'ye yönelik turizm talebini etkileyen faktörlerin panel veri yöntemiyle analiz edilmesi. 11. Ulusal Turizm Kongresi, Kuşadası, 2-5 Aralik, 2010, 44-57.

Gujarati D. N. ve Porter, D. C. (2014). Temel ekonometri. Ü. Şenesen ve G. G. Şenesen (Çev.), İstanbul: Literatür Yayıncılık.

Güneş, E., ve Kabadayı, B. (2015). Türkiye turizm talebini açıklamaya yönelik bir panel çekim modeli analizi. Çukurova Üniversitesi İktisadi ve İdari Bilimler Fakültesi Dergisi, 19(2), 31-46.

Habibi, F., Abdul Rahim, K., ve Chin, L. (2008). United Kingdom and United States tourism demand for Malaysia: A cointegration analysis. p.1-16. MPRA Papers.

Heckman, J. J. (1975). Dummy endogenous variables in a simultaneous equation system. National Bureau of Economic Research, Inc. 204 Junipero Serra Boulevard, Stanford, CA 94305

İbiş, S. ve Batman, O. (2015), Bölgesel kalkınmada turizmin rolünün yerel halkın görüşleri çerçevesinde belirlenmesi. İkinci Turizm ve Yönetim Araştırmaları Kongresi Bildiri Kitabı, 476-490, Kuşadası/Aydın.

İçöz, O., Var, T. ve Kozak, M. (1997). Tourism demand in Turkey. Research Notes And Reports. PII: S0160-7383 (97)00069-8.

Jintranun, J., Sriboonchitta, S., Calkins, P., ve Chaiboonsri, C. (2011). Thailand's international tourism demand: Seasonal panel unit roots and the related cointegration model. Review of Economics \& Finance, 63-76.

Kar, M., Zorkirişçi, E. ve Yıldırım, M. (2004). Turizmin ekonomiye katkısı üzerine ampirik bir değerlendirme. Akdeniz İ.I.B.F Dergisi, (8), 87-112 
Karafiath, I. (1988). Using dummy variables in the event methodology. The Financial Review, 23(3), 351-357.

Kaya, A. A., ve Canl1, B. (2013). Türkiye'ye yönelik uluslararası turizm talebinin belirleyenleri: panel veri yaklaşım. Anadolu University Journal of Social Sciences, 13(2), 43-54.

LaVeist, T. A. (1995). Beyond dummy variables and sample selection: what health services researchers ought to know about race as a variable. HSRK Health Services Research, 29(1), 116

Lim, C. (1997). Review of international tourism demand models. Annals of tourism research, 24(4), 835-849.

Lim, C., ve McAleer, M. (2002). A cointegration analysis of annual tourism demand by Malaysia for Australia. Mathematics and Computers in Simulation, 59(1-3), 197-205.

Ouerfelli, C. (2008). Co-integration analysis of quarterly European tourism demand in Tunisia. Tourism Management, 29(1), 127-137.

Schiff, A., ve Becken, S. (2011). Demand elasticity estimates for New Zealand tourism. Tourism Management, 32(3), 564-575.

Selçuk, G. N. ve Çatal, M. F. (2007). Turizmin Erzurum ekonomisi için önemi, Ekev Akademi Dergisi, $11(31), 297-306$

Sevinç, E. (2013). Çoklu regresyon korelasyon analizinde varsayımdan sapmalar ve çimento sektörü üzerine uygulama. 30 Mayls 2019 tarihinde http://serpam.org/wp-content/uploads/ Sevinc2013.pdf adresinden erişildi.

Şengel, Ü. (2015). Bitlis ilinin kalkınmasında turizmin rolü: yerel paydaşlar üzerine bir araştırma. Yayımlanmamış yüksek lisans tezi, Sakarya Üniversitesi Sosyal Bilimler Enstitüsü, Sakarya.

Taptık, Y. ve Keleş Ö. (1998). Kalite savaş araçları. İstanbul: KalDer Yayınları.

Tar1, R. (2016). Ekonometri: Geleneksel yöntemleri, zaman serileri analizi, panel veri analizleri. Kocaeli: KÜV Yayınları

Tatoğlu, F.Y. (2016). Panel veri ekonometrisi stata uygulamalı. İstanbul: Beta Yayıncılık.

Topall1, N. (2015). Turizm sektörünün Türkiye'nin ekonomik büyümesi üzerine etkisi: 1963-2011. International Journal of Economic and Administrative Studies, 7(14), 339-352

Wang, Y. S. (2009). The 1mpact of crisis events and macroeconomic activity on Taiwan"s international inbound tourism demand. Tourism Management, 30, 75-82.

Yeşiltaş, M. ve Öztürk, İ. (2008). Bölgesel kalkınma çerçevesinde alternatif turizm faaliyetlerine yönelik bir değerlendirme: Sivas Örneği. Cumhuriyet Üniversitesi İktisadi ve İdari Bilimler Fakültesi, 9(1), 1-18. 